\title{
Defluoridation of Drinking Water by Activated Carbon Prepared from Tridax Procumbens Plant (A Case Study of Gashaka Village, Hong L. G. A., Adamawa State, Nigeria)
}

\author{
Ahmad Hussaini Jagaba ${ }^{1, ~ *, ~ S u l e ~ A b u b a k a r ~}{ }^{1}$, Mohammed Abdu Nasara ${ }^{1}$, \\ Safiya Muhammad Jagaba ${ }^{2}$, Hayatu Mohammed Chamah ${ }^{3}$, Ibrahim Mohammed Lawal ${ }^{1}$ \\ ${ }^{1}$ Department of Civil Engineering, Abubakar Tafawa Balewa University, Bauchi, Nigeria \\ ${ }^{2}$ Department of Chemistry, Federal College of Education, Katsina, Nigeria \\ ${ }^{3}$ Federal Road Safety Corps, Bauchi, Nigeria
}

\section{Email address:}

ahjagaba@atbu.edu.ng (A. H. Jagaba), absadiqq@gmail.com (S. Abubakar), manasara@atbu.edu.ng (M. A. Nasara), jagabasafiya@gmail.com (S. M. Jagaba),hm.chamah@frsc.gov.ng (H. M. Chamah), ubawo04@yahoo.com (I. M. Lawal)

${ }^{*}$ Corresponding author

\section{To cite this article:}

Ahmad Hussaini Jagaba, Sule Abubakar, Mohammed Abdu Nasara, Safiya Muhammad Jagaba, Hayatu Mohammed Chamah, Ibrahim Mohammed Lawal. Defluoridation of Drinking Water by Activated Carbon Prepared from Tridax Procumbens Plant (A Case Study of Gashaka Village, Hong L. G. A., Adamawa State, Nigeria). International Journal of Computational and Theoretical Chemistry. Vol. 7, No. 1, 2019, pp. 1-5. doi: 10.11648/j.ijctc.20190701.11

Received: January 13, 2019; Accepted: February 26, 2019; Published: March 18, 2019

\begin{abstract}
Water is an essential element for the sustainability of human life on earth. Thus, portable drinking water is scarce and not readily available to all. Rural communities consume contaminated water and take ill periodically, which later results in epidemics. Contamination of drinking water may be caused by natural sources or industrial effluents due to domestic, agricultural and industrial activities. One of such contaminants is fluoride which is a salt of the element fluorine. Several treatment technologies for removing fluoride from groundwater have been investigated. This study focused on providing potable drinking water with fluoride level within the limit specified by the World Health Organization (WHO) to the people of Gashaka village. To achieve this, fluoride concentration and some physical properties in the water sample were determined. Subsequently, treatment of the sample by herbal means using activated carbon prepared from the stem of Tridax procumbens was carried out to prevent or minimise the effects of fluoride on human health such as skeletal fluorosis, dental fluorosis, fractures in bones, immune deficiency, cancer and other diseases caused by high concentration of fluoride in water since it possesses properties capable of greatly reducing fluoride concentration. The experimental result shows that fluoride concentration in the sample obtained was $2.3 \mathrm{mg} / \mathrm{l}$ which exceeds the $0.7 \mathrm{mg} / 1-1.2 \mathrm{mg} / \mathrm{l}$ range recommended by WHO. The effective contact time for fluoride removal was found to be 6 hours while the maximum dose of activated carbon for the effective removal of fluoride concentration in $100 \mathrm{mg}$ of water was found to be $1.05 \mathrm{~g}$ which removed $85.6 \%$. However, subsequent addition of the activated carbon tends to increase fluoride concentration in the sample.
\end{abstract}

Keywords: Activated Carbon, Defluoridation, Flouride, Portable Water, Tridax Procumbens

\section{Introduction}

Humans may survive for several weeks without food, but barely a few days without water because a constant supply of water is needed to replenish the fluids lost through normal physiological activities [1]. Lack of adequate potable water supply is a critical challenge in developing countries such as Nigeria. The importance of access to quality water is very essential to human consumption [2]. Potable water, also called drinking water in reference to its intended use, is defined as water which is fit for consumption by humans and other animals [1].

In Nigeria, a vast majority of people source and drink from 
rivers, streams, wells, boreholes, and other water bodies. These natural waters contain a myriad of microbial species, many of which have not been cultured, much less identified and are capable of causing disease. The most common waterborne diseases in Nigeria include cholera, typhoid, dracunculiasis, hepatitis etc [3]. Drinking water is usually contaminated by various pollutants such as fluorides, nitrates, iron etc. However, contaminants have different negative effects on human health.

Fluoride, which exists naturally in water sources abundantly, is derived from fluorine, a common element in the Earth's crust [4]. It does not occur in the elemental state in nature because of its high reactivity. In groundwater, fluoride concentrations vary with the type of rock water flows through but do not usually exceed $10 \mathrm{mg} / 1$ [5]. Humans are exposed to fluoride through different sources such as water, food, tea, beverages, pesticide residue on food, pharmaceutical drugs, kinds of toothpaste etc. [6]. Fluoride is known to have both beneficial and adverse effects on humans, depending on the total intake [7]. An intake of more than $6 \mathrm{mg}$ of fluoride per day results in fluorosis [4]. The crippling malady of fluorosis not only affects the bones and teeth, but every tissue and organ of the body, leading to death after a prolonged illness. It is a problem of public health importance [8]. Therefore, control of drinking-water quality is critical in preventing fluorosis [9].

Excessive fluoride concentration in water from hand dug wells of Gashaka village contaminates the water, thereby not making it portable for consumption. Continuous intake of such water led to the breakthrough of diseases like arthritis, enamel fluorosis and skeletal fluorosis among dwellers of the community. Therefore, it becomes necessary to provide an effective treatment method for removing fluoride from such water.

Several methods have earlier been developed for removal of fluoride in water. However, most of them require expensive and sophisticated devices that cannot be afforded by the common man at the village level. As a result, an attempt was made to assess the study of defluoridation [10]. Defluoridation refers to the method of water treatment that reduces the concentration of fluoride in water for safe human consumption. Some defluoridation techniques developed were water distillations, bone char carbon [11] coagulation, adsorption, precipitation, ion exchange, reverse osmosis, electrodialysis [9] Nalgonda technique and activated alumina. However, due to high cost, lower efficiency or nonapplicability on the mass scale, most of these techniques are not much in use. [4]. According to Jagaba [12], besides a large amount of sludge produced by most of these techniques, high level of salts remaining in the treated water has raised concern on public health.

Different plant species were studied for adsorption efficiency in fluoride removal [13]. A study by Gayathri [10] used amla powder, neem powder, coconut shell powder and turmeric powder where amla was best suited with the greatest extent of fluoridating capacity. Several researchers used sunflower plant dry powder, stem of phytomass, holly oke, neem bark powder, activated cotton jute carbon, bagasse ash, burnt bone powder, phosphate-treated saw dust, bone char, etc. as adsorbents [4]. An investigation was also carried out to explore the surface sorption abilities of activated powders of leaves, stems or barks of some herbal plants. Result obtained revealed that, leaves, stems or barks of Phyllanthus niruri, Annona squamosa, tridax procumbens, and morinda tinctori have an affinity towards nitrites [14].

Tridax procumbens popularly called "coat buttons" in the English Language is a spreading herb found in every part of Nigeria. It is popularly called 'Kashin Fara' or 'Abincin Zomo' in Hausa, which is a major language in the Northern part of the country. It is primarily grown during raining season and a medicinal herb that has been tested for the extraction of heavy metals from water [15]. Tridax procumbens has a great percentage of carbon. Therefore, it is responsible to form activated biocarbon used for adsorption. Activated biocarbon prepared from Tridax procumbens leaves are used to remove toxic heavy metals and dyes from industrial wastewater. Batch adsorption experiments were performed as a function of $\mathrm{pH}$, contact time, solute concentration and adsorbent dose [16].

Defluoridation of fluoride-containing drinking water is required for the healthy living of human beings [17]. Compared to other treatment methods and materials, adsorption using Tridax procumbens plant can be implemented at domestic or community levels as it is affordable by common man even in remote villages like Gashaka. Electricity is not required and it can be operated easily by anybody. Hence, these methods of using adsorbents are non-toxic and environmental friendly [10]. Therefore, this research investigates the herbal method of defluoridation by Activated Carbon prepared from Tridax procumbens (Coat buttons) plant.

\section{Materials and Method}

\subsection{Experimental Materials}

Several apparatus and reagents were used for the collection, preservation, characterization, and analysis of samples before, during and after treatment. This includes: water sample from Gashaka village, tridax procumbens plants from Yelwa area in Bauchi, distilled water, muffle furnace, colorimeter, evaporator dish, sample cell, beaker, measuring cylinder, $\mathrm{pH}$, digital meter, pipette, concentrated sulphuric acid and spading (fluoride reagent).

\subsection{Water Sample Collection}

Water sample used for this study was collected from hand drilled well of Gashaka Village, Hong Local Government, Adamawa State. The sample was collected in a sterile plastic container, sealed tight and labeled to ensure that the collection device from hand dug well does not come in contact with the sterile plastic container and all other necessary precautions were done to avoid any external contaminant [18]. It was later transported to the Sanitary 
Laboratory, Department of Civil Engineering, ATBU, Bauchi for the examination of fluoride concentration. Physical properties of the water sample such as $\mathrm{pH}$, electric conductivity, color, temperature and total dissolved solids (TDS) were determined. To prevent the sample from undergoing biodegradation due to microbial action, it was preserved by refrigerating at about $4^{\circ} \mathrm{C}[18]$.

\subsection{Preparation of Activated Carbon}

Tridax procumbens plants were collected from a site somewhere around A. T. B. U. Bauchi, Yelwa Campus as can be seen in Figure 1 below, followed by the separation of stems from leaves and flowers. They were thoroughly washed, cleaned, divided into pieces and then placed into muffle furnace at a temperature of $440^{\circ} \mathrm{C}$ for 120 minutes using the evaporating dish in the Chemistry laboratory, Federal Polytechnic Bauchi. After it has been dried off completely, $25 \%$ by volume of concentrated Sulphuric Acid was added and again kept in the furnace for 30 minutes at the same temperature of $440^{\circ} \mathrm{C}$ as described by [19]. The product obtained is known as activated carbon prepared from Tridax procumbens stem.

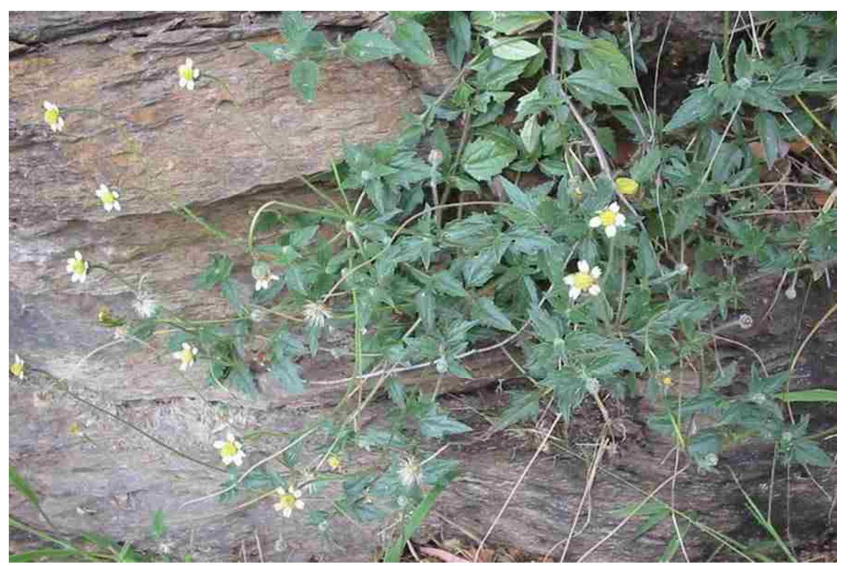

Figure 1. Tridax Procumbens Plant.

\subsection{Test Preparation}

$100 \mathrm{ml}$ beaker was filled with a water sample, $0.15 \mathrm{~g}$ of activated carbon prepared from Tridax procumbens plants was added and thoroughly mixed which allowed it to settle. At each three (3) hours interval, the test was carried out for 24 hours to determine the effective contact time for fluoride removal by the activated carbon. Fluoride testing was carried out using colorimeter which is a digital measuring device for fluoride and other elements in water. Distilled water was used throughout the tests as a control or zeroing the testing device [20].

Eight beakers of $100 \mathrm{ml}$ were arranged and numbered 1-8. Each filled with water sample alongside $0.15 \mathrm{~g}, 0.30 \mathrm{~g}, 0.45$ $\mathrm{g}, 0.60 \mathrm{~g} 0.75 \mathrm{~g}, 0.90 \mathrm{~g}, 1.05 \mathrm{~g}$ and $1.2 \mathrm{~g}$ of activated carbon added to the beakers which were later mixed thoroughly. They were all allowed to settle for six (6) hours and then fluoride level of each beaker was determined.

$10 \mathrm{mg}$ of water sample was pipetted and poured into the sample cell and $2 \mathrm{mg}$ of SPADINS (fluoride reagent) was added. Also, $10 \mathrm{mg}$ of distilled water was poured into another sample cell and $2 \mathrm{mg}$ of SPADINS (fluoride reagent) was also added. Both of two sample cells were shacked very well to provide a homogeneous mixture between the water sample and the fluoride reagent. The sample cell containing distilled water called blank was first placed into colorimeter to zero the device then sample cell containing sample water was placed for fluoride concentration test [19].

\section{Analysis and Discussion of Result}

\subsection{Physical Characterisation of Water Sample}

Physical properties of the water sample such as $\mathrm{pH}$, Colour, Turbidity, Electric conductivity, Temperature and Total Dissolved Solids (TDS) were determined to compare with the recommended standard and the results are shown in Table 1 below. According to the results, the physical properties of the water sample met the World Health Organisations recommended standard [21]. Turbidity and color test of the water sample was determined using the same device (Colorimeter) while $\mathrm{pH}$, TDS, Temperature and Electric conductivity of the water sample were determined using HI 98113-5 Digital meter.

Table 1. Initial Physical Characteristics of the Raw Sample.

\begin{tabular}{lll}
\hline Test & $\begin{array}{l}\text { Raw water } \\
\text { sample }\end{array}$ & $\begin{array}{l}\text { Recommended } \\
\text { Standard (WHO, 2007) }\end{array}$ \\
\hline $\mathrm{pH}(\mathrm{ms} / \mathrm{cm})$ & 0.89 & $6.5-8.5$ \\
Electric-conductivity $(\mathrm{ms})$ & 0.3 & $1000 \mu \mathrm{s} / \mathrm{cm}$ \\
TDS (ppm) & 217 & $500 \mathrm{mg} / \mathrm{L}$ \\
Turbidity $(\mathrm{NTU})$ & 1 & $5 \mathrm{NTU}$ \\
Colour & 0 & $50 \mathrm{Pt} . \mathrm{co}$ \\
Temperature $\left({ }^{\circ} \mathrm{C}\right)$ & 25.2 & - \\
\hline
\end{tabular}

\subsection{Determination of Effective Contact Time}

Fluoride concentration of water sample was found to be $2.30 \mathrm{mg} / 1$ which is above the recommended standard by WHO $0.7 \mathrm{mg} / 1$ to $1.2 \mathrm{mg} / \mathrm{l}$ and not portable for drinking since it exceeds the recommended standard. $0.15 \mathrm{~g}$ of Activated carbon prepared from the stem of Tridax procubens plants was used in $100 \mathrm{mg}$ of the water sample to determine the effective contact time of fluoride removal and the results are shown in Figure 1 below which is a graph of fluoride concentration against contact time. The concentration was determined using the expression in equation (1):

Fluoride concentration $(\mathrm{C})=[$ initial fluoride concentration $\left(\mathrm{C}_{\mathrm{o}}\right)$ ] - [final fluoride concentration $\left(\mathrm{C}_{1}\right)$ after each three hours interval].

Mathematically,

$$
\mathrm{C}=\mathrm{C}_{\mathrm{o}}-\mathrm{C}_{1}
$$




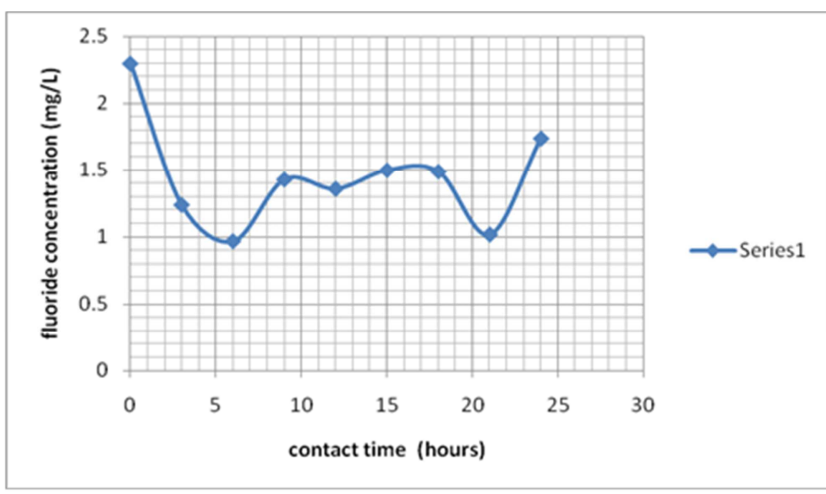

Figure 2. Fluoride Concentration Against Contact Time.

Figure 2 above is a graph of fluoride concentration against contact time which indicates that at three (3) hours, fluoride concentration reduced while at six (6) hours, it was reduced the most. However, at nine (9) hours, the fluoride concentration increased while at twelve (12) hours it was reduced which continuously kept fluctuating at every three (3) hour interval for up to twenty-four (24) hours. Therefore, the effective contact time was determined as six (6) hours.

\subsection{Determination of Effective Dose of Activated Carbon}

Effective dose of activated carbon was determined by keeping the effective contact time of six (6) hours obtained during the first phase of the experiment as constant while addition of activated carbon dose into the water sample was varied in from $0.15 \mathrm{~g}, 0.30 \mathrm{~g}, 0.45 \mathrm{~g} 0.60 \mathrm{~g}, 0.75 \mathrm{~g}, 0.90 \mathrm{~g}$, $1.05 \mathrm{~g}$ up to $1.20 \mathrm{~g}$. The effective dose was determined based on fluoride removal efficiency using the expression in equation (2):

$$
\% \text { of fluoride removal }=\frac{C_{0}-C_{1}}{C_{0}} \times 100
$$

Where:

$\mathrm{C}_{\mathrm{o}}=$ Initial fluoride concentration

$\mathrm{C}_{1}=$ Final fluoride concentration

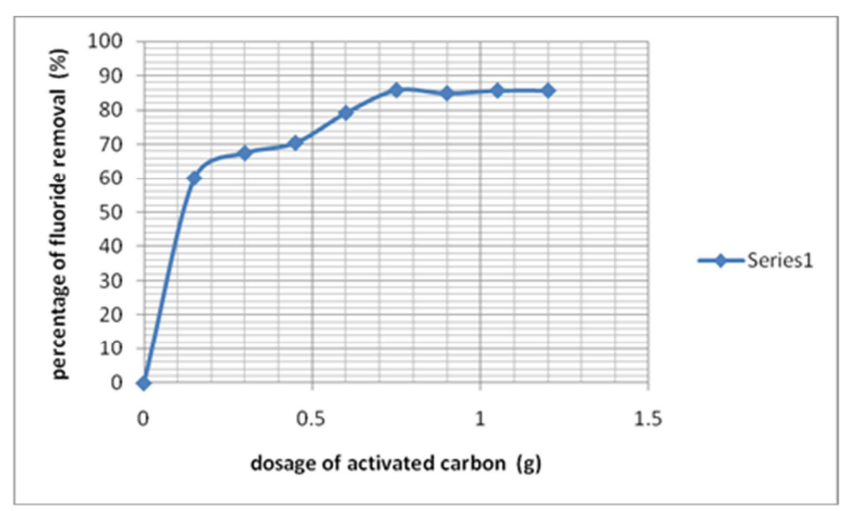

Figure 3. Percentage of Fluoride Removal Against Dosage of Activated Carbon.

Figure 3 is a graph of fluoride removal efficiency against a dose of activated carbon in the water sample. It shows that increment in the dose of activated carbon, the more fluoride concentration is reduced until fluoride concentration reduces no more at $1.05 \mathrm{~g}$ of activated carbon. Therefore, the maximum dose of activated carbon prepared from tridax procumbens for the effective removal of fluoride concentration in $100 \mathrm{mg}$ of water is $1.05 \mathrm{~g}$ which removed $85.6 \%$ while $0.15 \mathrm{~g}$ also in $100 \mathrm{mg}$ removed only $60 \%$ within the same time.

\section{Conclusion}

Defluoridation of fluoride-containing drinking water in Gashaka village is required for the healthy living of its inhabitants. Since the use of adsorbents is mostly simple, cheap, non-toxic and environmentally friendly, its adoption for the defluoridation of drinking water at the village becomes necessary. Because of the maximal availability of Tridax procumbens plant in the village, the study used the plant's stem for activated carbon preparation. Physical properties of water sample were determined which conforms to the recommended standard by WHO. At the end of the experiment, it became evident that the adsorbent used have no negative effect on the physical properties of water, except electric conductivity which increases with the addition of activated carbon into the water sample. The significant results were being obtained from the experiment without disturbing the $\mathrm{pH}$ of the water and show that $2.30 \mathrm{mg} / \mathrm{l}$ of fluoride concentration is present in the water sample. It also confirms that activated carbon prepared from Tridax procumbens possess the ability to absorb a large quantity of fluoride from water. Based on the experiment carried out, it became evident that the recommended effective contact time for fluoride removal is six (6) hours while $1.05 \mathrm{~g}$ of activated carbon is the maximum dose required for effective fluoride removal in $100 \mathrm{mg}$ of water. Hence, fluoride concentration in the case study area was drastically reduced to $0.33 \mathrm{mg} / \mathrm{l}$ resulting in $85.6 \%$ adsorption efficiency.

\section{Acknowledgements}

Authors would like to express their gratitude to the Head of Department, Prof. A. Mohammed and the entire staff of the Civil Engineering Department, A. T. B. U. Bauchi for their contributions from the beginning of the study to the end. A very special thanks and appreciation to the District Head of Gashaka Village and various community members with their understanding and permission, samples were obtained from hand dug wells for the study. Appreciation also goes to Mrs. CL Danbaba and all the FRSC staff of RS12HQ Bauchi for the maximum support rendered during the study period.

\section{References}

[1] N. O. Shalom, C. Nwinyi, Y. Adetayo \& N. E. Vivienne, (2011). Assessment of water quality in Canaanland, Ota, Southwest Nigeria. Agriculture and Biology Journal of North America. 
[2] S. Abubakar, I. M. Lawal, I. Hassan, A. H. Jagaba (2016). Quality Water Analysis of Public and Private Boreholes (A Case Study of Azare Town, Bauchi, Nigeria). Americal Journal of Engineering Research 5(2):204-208.

[3] O. F. Nwabor, E. I. Nnamonu, P. E. Martins, \& O. C. Ani (2016). Water and Waterborne Diseases. International Journal of Tropical Disease \& Health.

[4] A. V. Jamode, V. S. Sapkal and V. S. Jamode (2004). Defluoridation of Water Using Inexpensive Adsorbents, J. Indian Inst. Sci., 84:163 - 171.

[5] World Health Organization (2004). Fluoride in drinking-water, background document for development of who guidelines for drinking-water quality.

[6] M. Aghaei, M. Darakhshari, M. Raoof, M. Deligahi, and A. H. Mahvi (2015). Effect of fluoride in drinking water on birth height and weight. Research report Fluoride 48(2):160-168.

[7] L. Aggerborn and M. Othman (2016) The Effects of Flouride in the Drinking Water. JEL Classification: I10, H42: I18.

[8] S. Nazneen (2012). Study of Fluoride Concentration in the River (Godavari) and Groundwater of Nanded City. International Journal of Engineering Inventions. 1(1):11-15.

[9] M. Singanan (2013). Excessive Fluoride in drinking water can affect human health. Int. J. of Environmental Engineering, $5(2): 150-160$.

[10] G. Gayathri, B. C. Kumar Raju, D. S. Reddy and M. Beulah (2017). Defluoridation of Ground Water Using Low-Cost Adsorbents. International Journal of Earth Sciences and Engineering. 10(5):967-972.

[11] N. A. Ingle, H. V. Dubey, N. Kaur, \& A. Nagpal, (2014) Defluoridating Water. British Dental Journal 216:437.

[12] A. H. Jagaba, S. Abubakar, I. M. Lawal, Ab Aziz Abdul Latiff, I. Umaru, (2018). Wastewater Treatment Using Alum, the Combinations of Alum-Ferric Chloride, Alum-Chitosan,
Alum-Zeolite, and Alum- Moringa Oleifera as Adsorbent and Coagulant. International Journal of Engineering Management. 2(3):67-75.

[13] S. P. H. Puthenveedu, J. Chonattu, M. Tharayil (2012). Defluoridation of water using biosorbents. Natural Science, 4(4):245-251.

[14] M. Suneetha and K. Ravindhranath (2012). Removal of Nitrite from Polluted Waters using Bio-sorbents derived from Powders of Leaves, Barks or Stems of Some Herbal Plants. International Journal of Chemical, Environmental and Pharmaceutical Research, 3(1):24-34.

[15] S. S. Pingale (2013). Study of Antimicrobial Potential of Tridax Procumbens L. Int. J. Bioassays, 2(6):866-869.

[16] N. H. Pathode and D. V. Parwate (2015). Separation of Ni(II) and $\mathrm{Hg}(\mathrm{II})$ ions from synthetic wastewater by adsorption on activated carbon derived from Tridax procumbens. International Journal of Innovative Research in Science, Engineering and Technology 4(12).

[17] T. K. Rao, I. V. Kasiviswanath and Y. L. N. Murthy (2009). Defluoridation of water by nanotechnology. Journal of Water Science \& Technology. 9.5:485-491.

[18] APHA (2005). Standard Method for the Examination of Water and Wastewater. American Public Health Association, Washington. 21st Edition.

[19] P. C. Raghavendra, H. S. Manjunath \& K. S. Jayantha (2015). Defluoridation studies using activated carbon prepared from 'Tridax procumben' plant. International Journal of Scientific \& Engineering Research, 6 .

[20] C. Janardhana, G. N. Rao, R. S. Sathish \& V S. Lakshman (2006). Study on defluoridation of drinking water by impregnation of metal ions in activated charcoal. Indian Journal of Chemical Technology, 13:414-416.

[21] World Health Organization (2007). Guidelines for DrinkingWater Quality. 